\title{
The Image of Narrative Prosthesis in McDonagh's The Pillowman: Normality vs. Psychopathology
}

\section{McDonagh'in Yastik Adam (The Pillowman) Oyununda Anlatı Protezi: Psikopatolojiye Karşı Normallik}

\author{
Önder ÇAKIRTAȘ ${ }^{10}$
}

${ }^{1}$ Assist. Prof., Bingol University, Faculty of Arts and Sciences, Department of English Language and Literature, Bingol, Turkey

\author{
Corresponding author: \\ Önder ÇAKIRTAŞ, \\ Bingöl Üniversitesi, Fen Edebiyat Fakültesi, \\ İngiliz Dili ve Edebiyatı Bölümü, 12000, \\ Merkez, Bingöl, Türkiye \\ E-mail: cakirtasonder@gmail.com \\ Date of receipt: 15.04 .2018 \\ Date of acceptance: 17.05 .2018 \\ Citation: Çakırtaş, Ö. (2018). The image of \\ narrative prosthesis in McDonagh's The \\ Pillowman: Normality vs. psychopathology. \\ Litera, 28(1), 33-51. \\ https://doi.org/10.26650/LITERA398079
}

ÖZ

Bu çalışma, David Mitchel ve Sharon Synder'in 'engellilik çalışmaları' şemsiyesi altında tanıtılan anlatı protezi bağlamında, postmodern İngiliz oyun yazarı Martin McDonagh tarafından yazılan kayda değer oyunlarından Yastık Adam'ı incelemeyi amaçlar. Çalışma, Mcdonagh'ın bahsi geçen oyunundaki karakterleri edebi özelliklerine göre, engellilik çalışmalarındaki bedensel/mental "normallik" ve "engellilik" kavramlarılya ilişkili olarak inceler. Bu bağlamda, çalışma, McDonagh'ın oyunun anlamsallığını artırmasını sağladığı 'engelli' karakterlerin'varoluşçu'yönlerinin yanında, anomali siyaseti ve anlatı ve engellilik ilişkisine dair sonuçlar etrafında döner. Makale, anlatı protezi kavramı ve engelliliğin doğasını, politiğini ve sonuçlarını kültürel, sosyal ve edebi bir yapı olarak inceleyip entelektüel bir disiplin olarak ifade edilen ve güncel bir yaklaşım olan kritik engellilik çalışmaları üzerine bir dizi yorumu içerir. Bu nedenle bu makale, anlatı protezinin, oyun ve ilgili eserlerdeki referanslara odaklanarak yazar-oyun ilişkisi yoluyla uygulanabilirliğini bulmaya çalışır. Bu bağlamda, bu makale McDonagh'ın 'engelli'karakterler ile olgunlaşan oyununu da'kültürel ve edebi yatırım' objektifinde inceleyecektir.

Anahtar Kelimeler: Martin McDonagh, Yastık Adam, Anlatı Protezi, Psikopatoloji, Normallik

\section{ABSTRACT}

This study aims to examine The Pillowman - a noteworthy play written by the postmodern British playwright Martin McDonagh-in the context of the narrative prosthesis introduced by David Mitchel and Sharon Synder under the umbrella term 'disability studies'. The study examines the characters in Mcdonagh's play in terms of their literary characteristics in relation to the concepts of 'normalcy' and 'disability' within disability studies. In this context, the study revolves around McDonagh's creation of 'existential' aspects of 'disabled' characters which has implications for the meaning of the play, the politics of the anomaly, and the narrative and disability relationship. The article explains the concept of narrative prosthesis as well as a number of interpretations on Critical Disability Studies, a current approach which is an intellectual and educational discipline studying the implication, nature, and consequences of disability as a cultural, social and literary construct. For this reason, this article tries to find out the applicability of the narrative prosthesis through the author-play relationship focusing on references from the play and related works. In this respect, this article will also examine McDonagh's play, which is enriched by 'disabled' characters, in the lens of 'cultural and literary investment'. Keywords: Martin McDonagh, The Pillowman, Narrative Prosthesis, Psychopathology, Normalcy 


\section{EXTENDED ABSTRACT}

In addition to being a multidisciplinary field of study, critical disability studies have also been adopted by literary thinkers as one of the most widespread work areas of recent times. Narrative Prosthesis, introduced by Sharon Snyder and David Mitchell, both of whom are key theorists of critical disability studies, discusses the way narrative makes use of disability as a tool of representation or metaphor, but fails to further cultivate disability as a multifaceted approach. Thus, the narratability of disability here depends on obtaining some conclusions on the normality of the characters. Martin McDonagh's characters in The Pillowman represent disabled persons who behave as a "crutch upon which literary narratives lean for their representational power, disruptive potentiality, and analytical insight" (Mitchell \& Snyder, 2000, p. 49). However, this leaning is driven by the psychopathological aspects of the characters.

The term psychopathology, which has its root in the Greek words 'psyche' (soul), 'pathos' (suffering) and 'logos' (the study of), refers to the appearance of behaviour that points out the incidence of a psychological chaos. Some of the greatest strains of modern society are the psychological ones. World wars are also the greatest factors that increase the anxiety of modern society. Reflecting on the uncontrolled post-war society, McDonagh reveals man's psychopathology through the psychological and mental strains of various characters. In this play, characters are in a struggle with a psychological situation. Interrupted speech, unconnected expressions, collective monologues are a sign that consciousness is not in a normal state at all. For instance, dialogues between Katurian and Michal and the detectives are indicative of a mental and psychological illness. In the same way, the words spoken are a reflection of depressed mood, and their timid movements are those of physical decadence. The purpose of this study is to try to explain normality as against psychopathology in characterization within The Pillowman taking Narrative Prosthesis to the centre. In order to accomplish this purpose, the work is divided into several sections.

The introduction to the study includes a number of analyzes and literature on critical disability studies. In this context, the reason why this work emerged is explained, and some writings by important scholars are cited. The emphasis is placed on the concept of 'narrative prosthesis', a new model emerging from the ideas of different scholars in this field of study, and notes on the purposes and examinations 
that cause this concept to gain importance are evaluated. In addition to the concept of narrative prosthesis, the notion of 'materiality of metaphor', another important theory with a different narrative connotation, is also examined. Later on in the work, the main subject comes to the fore and an attempt to relate McDonagh's The Pillowman to the narrative prosthesis concept is made. On this subject, the study attempts to gain semantic integrity with various quotations from the play. Through the conclusions and interpretations made, the work supports the above-mentioned concepts and definitions. 


\section{Introduction}

In the essay, Narrative Prosthesis and the Materiality of Metaphor, David Mitchell and Sharon Snyder start their introductory statements with these words: "Nearly every culture views disability as a problem in need of a solution, and this belief establishes one of the major modes of historical address directed toward people with disabilities" (2006, p. 205). People are attempting to find solutions to this problem within the context of the awareness of cultures they embrace. And these solutions have led to the creation of a huge platform in which a range of disciplines are involved: Critical Disability Studies (CDS).

Critical Disability Studies is a recent theoretical forum that aims to establish the conceptualization of disability and its reflections upon human sciences. Disability studies think of disability in many different disciplines ranging from cultural studies and politics, to aesthetics, ethics and sociology among others. In literary studies, numerous scholars aim to use the writings to comprehend how images of disability and 'normal' bodies alter during the course of time, and they search for the methods that are demarcated within the parameters of historical or socio-cultural circumstances. Besides these, the scholars of CDS go into metaphors and portrayals of disability, including bias against people with disabilities (ableism), to establish a prodigious spectrum of this scholarship.

The various specialists who have pioneered the emergence of this field have emphasized different points of view. Kirsty Johnston advocates that "Disability has a long and complex cultural history that raises fundamental questions about identity, definitions of normalcy and social conditions of everyday life" (2016, p. 15). In this context, identity, normality and social attitudes and behavior are observed as the main elements of this field of study. Lennard J. Davis, an expert in this field of study, examines the existence of 'disability' outside of the relationship between 'normal' and 'abnormal', and he writes "To understand the disabled body, one must return to the concept of the norm, the normal body" (1995, p. 23), and he continues,

So much of writing about disability has focused on the disabled person as the object of study, just as the study of race has focused on the person of color. But as recent scholarship on race, which has turned its attention to whiteness, I would like to focus not so much on the 
construction of disability as on the construction of normalcy. I do this because the 'problem' is not the person with disabilities; the problem is the way that normalcy is constructed to create the 'problem' of the disabled person. (pp. 23-24)

Davis goes to the root of the word 'norm' to explain this approach and he pays attention to the social acceptance of the concepts 'average' and 'ideal' within the context of the relationship between norm and normality produced by widespread use' (pp. 24-25). In this context, Davis cites a few steps of how the concept of 'ideal' has been redefined by various scholars and gives a new perspective on the existence of the concept of disability in the human body.

Another important context in which experts have been producing ideas around the concept of normality is the difference between the concepts of 'disability' and 'impairment'. David Mitchell and Sharon Snyder write that "The trend in disability studies for years has been to distinguish between disability and impairment, arguing that the latter term is a neutral designator of biological difference while the former represents a social process termed "disablement" $(2006$, p. 6$)$. In this context, these two scholars state that the studies conducted up to this point (including the work of the World Health Organization) exclude this concept from disability studies because the concept of impairment is related to biological elements (pp. 6-7). For this reason, confirming the existence of the 'social disability model' and pointing to a different aspect of this model, Mitchell and Snyder, who think that it is more appropriate and meaningful to put the two together, introduce an important theory as 'cultural disability model', since they believe that "[ $t]$ he definition of disability must incorporate both the outer and inner reaches of culture and experience as a combination of profoundly social and biological forces" (p. 7). In fact, the attempt to produce such a model is concerned with the scholars' (of disability studies) dismissal of "opportunities to theorize this interactional space between embodiment and social ideology" (p. 7). As claimed by Johnston, "[c]oming from a range of different perspectives, disability studies scholars argued that the medical model problematically treated disability as an individual condition while ignoring the social and cultural context in which it

1 The situation that Davis originally suggests is the relationship between the words 'normal' and 'ideal'. In this context, the word 'normal' is associated with the word 'average', while the word 'ideal' means what everyone cannot have. As he writes "The notion of an ideal implies that [...] the human body as visualized in art or imagination must be composed from the ideal parts of living models. These models individually can never embody the ideal since an ideal, by definition, can never be found in this world." (24) 
existed" (2016, p. 18). For this reason, these models (social and cultural) have been adopted to gain a holistic experience.

In addition to the above, there is an original theory that has been produced as part of the cultural model. This theory, originated by Snyder and Mitchell as narrative prosthesis, provides a critical interpretation by bringing together the concepts of 'narrative' and 'disability'. Since the core of this work will be shaped around this concept, an explanation of what it refers to must first be made.

\section{Narrative Prosthesis and the Disability Theatre}

Recently coined and devised by two American scholars, David Mitchell and Sharon Snyder, narrative prosthesis examines the ways in which narrative relates to disability. In its simplest sense, narrative prosthesis is "the dependency of literary narratives upon disability" (2006, p. 226). The two above-mentioned critics argue that the integrity of the text is entirely concentrated around the concept of 'disability', and through narrative prosthesis they "address the meanings assigned to disability as a representational identity in narrative art" (2000, p. 1). With a more general idea, Mitchell and Snyder write that

In Narrative Prosthesis we mean to help locate disability's place on the map of multicultural studies. Our readings situate disability, like gender, sexuality, and race, as a constructed category of discursive investment. In fact, as we have argued elsewhere (The Body and Physical Difference, introduction), physical or cognitive inferiority has historically characterized the means by which bodies have been constructed as "deviant": the Victorian equation between femininity and hysteria; the biological racism that justified slavery and the social subordination of racial minorities; psychiatry's categorization of homosexuality as a pathological disorder; and so on. This socially imposed relationship between marginalized populations and "inferior" biology situates disability studies in proximity to other minority approaches. Like these other identity-based areas of inquiry, disability studies challenges the common ascription of inferior lives to persons with physical and cognitive differences. $(2000$, p. 2$)$ 
For these reasons, in the context of cultural studies, these two experts aim to contact the literary/narrative assets of disabled people over and above the biological assets mentioned by some differing scholars. When examining the background for introducing this avant-garde idea, they base the concept on the existence of a 'problem', which, according to them, is actually a 'problem' in itself. The reason for this is related to how the concept of 'disability' is discussed and interpreted in narratives. They take the view that, apart from the various treatment processes of individuals having these disabilities, the narratives related to them are also highly variable. According to the two scholars, "their function in literary discourse is twofold: disability pervades literary narrative, first, as a stock feature of characterization and, second, as an opportunist metaphorical device" $(2006$, p. 205). The basic idea here is that in the former "disability serves as a primary impetus of the storyteller's efforts" while in the latter, "disability [...] serves as a metaphorical signifier of social and individual collapse" (p. 205). The two factors that the scholars state as the reasons for the representation of 'disability' in narratives are actually related to the concepts of 'norm' and 'normalcy'. In view of the fact that the concept of 'disability' means that the body cannot fulfil one or more of its functions, 'disability' has an opposite interaction with the concept of 'norm.' For this reason, the narratives are shaped around the abnormal, as "[d]isability lends a distinctive idiosyncrasy to any character that differentiates the character from the anonymous background of the 'norm"' (p. 205). Moreover, they employ 'bodily deviance' to denote the opposition of bodily normality.

In fact, Mitchell and Snyder suggest that the use of the concept of 'disability' in literary texts in the cultural context is more a reinforcement rather than a negation, as "narrative prosthesis adds a marked physical difference, a sign of transgression or deviance, and then either resolves the crisis by regaining normalcy by overcoming the disability, or the disability brings the disabled character or thing to an apocalyptic end" (Higl, 2016, p. 168). For this reason, various scholars of narrative prosthesis predict that the use of 'disabled' characters existing in the texts may help create an act of normalization and naturalization, and therefore regard it as a literary investment. The word 'investment' here is as metaphorical as the metaphorical use of the concept of disability in literary texts. The reason is that

While disability can be used to naturalize a fall by lending it a sensible cause, disability is also a metaphor for a fall, and fall is a metaphor for disability, and both are made to count for life changes cast as 
undesirable departures from normalcy. Disability is a readily available term to metaphorically express collapse, loss, failure, defeat, decline, or an unwanted and unwelcomed state of affairs. (Titchkosky, 2016, p. 311)

Literary investment, therefore, comprises disability which "serves as an interruptive force that confronts cultural truisms" (Mitchell \& Snyder, 2006, p. 206). According to Mitchell and Snyder, "The inherent vulnerability and variability of bodies serves literary narratives as a metonym for that which refuses to conform to the mind's desire for order and rationality" (p. 206) by which they propose a metaphorical use of 'disability' instead of exact portrayal of 'normalcy' or 'ability', and they continue, "Within this schema disability acts as a metaphor and fleshly example of the body's unruly resistance to the culture desire to 'enforce normalcy'" (p. 206). The fall, failure, defeat, loss, or any unwanted states mentioned above, thus become metaphorical makings of disability.

Alice Hall, in Literature and Disability, submits that "the theory of narrative prosthesis provides a powerful framework through which literary disability studies critics have challenged the ways in which disability metaphors are used to aestheticize and depoliticize disability issues" (2016, p. 37). In this regard, there have been a number of attempts to improve these metaphorical uses in terms of aesthetics and depoliticization, for instance, addressing disabled people "to create art that [express] and [explore] disability as a valued human condition" (Johnston, 2016, p. 21). One of the most important of these is the type of art called Disability Theatre. According to Johnston, an expert in cultural disability research and writer of one of the first books on this art,

[D]isability theatre is broadly connected to impulses for social justice in the face of ableist ideologies and practices as well as a profound recognition of disabled lives and experiences as inherently valuable, particularly in their connection to the full expression of what Mitchell and Snyder describe above as "human variation." (25)

Despite the fact that this issue challenges the institutionalization of 'disabled people' under the umbrella of practical theatres and institutions, it should also be addressed in the context of narrative prosthesis to reveal the metaphorical or political implications employed by writers. This leads to a contradiction between the basic 
purpose of disability theatre that Johnston claims and the narrative prosthesis that "[d]isability is represented not for its own sake, but instead used to shore up and stabilize ideas of the normal or to tell readers something about the plot and deepen understandings of central, non-disabled characters" (Hall, 2016, p. 37). However, they are both compromised as a consequence of 'aesthetic' and 'political' orientations, since "[d]isability theatre may [...] be best understood as a kind of theatre-making that draws from disability culture's challenges to ableism and comprises a growing international field of practice remarkable for its political force, artistic re-imagining of theatre traditions, and lively aesthetic debates" (Johnston, 2016, p. 26).

Being "both activist and artistic in orientation" (p. 15), disability theatre "is rooted in a kind of cultural provocation, in this case a word pairing that rests on the hardwon recognition of disability arts and culture's place and stake in theatre" (p. 35). Focusing more on the performance function in his research, Johnston in the other sections of his research presents a review of the disability concept of various theatrical texts of different researchers. For instance, in a chapter written by Michael Davidson in Johnston's collection, the 'disabled' characters in the Beckett theatre are examined and the concept of 'abject dependency', as a part of disability studies, is discussed (pp. 109-113).

\section{Narrative Prosthesis and The Pillowman}

Roland Barthes refers to the functioning of the cognitive mechanisms of writers when he emphasizes that "[t]hus every writer's motto reads: mad I cannot be, sane I do not design to be, neurotic I am" $(1975$, p. 6) in The Pleasure of Text, and tries to explain the state of 'pleasure' as a counterpart in the writers' works. He continues with these words: "The text you write must prove to me that it desires me. This proof exists: it is writing. Writing is: the science of various blisses of language [...]" (p. 6) by which he refers to the responsibility of any literary text for giving any reader pleasure. Martin McDonagh's The Pillowman gives the feeling of such responsibility and is intended to give readers pleasure. This responsibility, however, causes the playwright to try to overuse the concept of 'disability' and to create the greater part of his work around 'disabled' characters. Being a model of 'the play within the play', The Pillowman centres on the 'pleasure' which causes a writer to create stories and thus to be able to write. There are unusual characters in this play. In an interrogation room in an unnamed totalitarian dictatorship, Katurian Katurian, a writer, is being interrogated by two 
detectives, Ariel and Tupolski. Next door, Katurian's mentally disabled brother Michal is waiting. The detectives want to know why Katurian's stories feature gruesome plots about child murder and torture, and in particular, why they seem to mirror a string of recent child murders in the area. Katurian mentions a different story in each of his defences, and his content is as interesting as the difference in the stories.

In the play, the characters construct a differing vision of their own selves. On the basis of this, of course, childhood has a lot of influence. False childhood processing, fear, violence, psychological traumas are the underlying factors of behavioural disorders currently experienced by Katurian Katurian and Michal in the play. First the readers are invited to think that the characters are mad when they read the play. The detectives' attitudes also have a number of behavioural disorders. As conversations turn to the depths of mental disorders, the presence of very serious traumas comes to light. Violence turns into mediocrity, but new violence arises as the story of violence is narrated. The tragic story of Katurian Katurian, who strangled his parents, and Michal, the 'mentally-disabled' who murdered children, unleashes postmodern human distress. For this reason, this play is important both in terms of psychoanalytic as well as disability studies.

At the beginning, McDonagh gives the impression that the characters he creates are normal with their identities. This is the politics of his writing, since he continues to write over the differences between normal and abnormal, which immediately reminds us of Mitchell and Snyder's rhetoric of "opportunistic metaphorical device" (p. 47) employed in narrative prosthesis which is interpreted by Louise J. Lawrence as a device denoting "social and individual collapse" (2013, p. 32). What I mean here is exactly what Mitchell and Snyder signify within their informative words: "disability acts as a metaphor and fleshly example of the body's unruly resistance to the cultural desire to enforce normalcy" (2000, p. 48). McDonagh tries to make the concept of normalcy strong in two ways: In the first, he makes a 'normal' entry around the ambiguity of reading; in the second, he tries to achieve the normality of the individual through 'psychopathological characterization', because he first tries to reveal the concept of 'normalcy' with an affirmation and then with a negation. Andrew Higl, in one of his chapters on this subject, presents this situation as a 'problem to be solved', and to him, "the marked difference or deviance is something that must be resolved, and the resolution of the deviance is closure" $(2016, \mathrm{p} .168)$. The marked difference in any character in the play is first introduced with Michal: 
ARIEL. He's backward, your brother, yeah?

KATURIAN. He's not backward, no. He's slow to get things sometimes.

ARIEL. He's slow to get things. Okay. (p. 8)

Here, the marked difference is with Michal, though the 'thing to be resolved' is not only with Michal's bodily/mental deviance. There is an actual 'marked difference' in Katurian's way of implotment as well, which is in point of fact a mental deviance. Such noticeable peculiarity in Katurian's implotments in turn marks the presence of a problem and its gradual dissolution. The attempt by McDonagh to solve a problem with such narrations is highly thought-provoking, for, firstly, a psychopathological mood emerges as the stories are restored, and secondly, Michal and Katurian's 'disability' problem becomes more problematic and then each narrative is unravelled like a riddle. This is related to 'materiality of metaphor'2 as reflected in the following words:

Like Oedipus (another renowned disabled fictional creation), cultures thrive upon solving the riddle of disability's rhyme and reason. When the limping Greek protagonist overcomes the Sphinx by answering "man who walks with a cane" as the concluding answer to her three-part query, we must assume that his own disability served as an experiential source for this insight. The master riddle solver in effect trumps the Sphinx's feminine otherness with knowledge gleaned from his own experience of inhabiting an alien body. In doing so, Oedipus taps into the cultural reservoir of disability's myriad symbolic associations as an interpretive source for his own riddle-solving methodology. Whereas disability usually provides the riddle in need of a narrative solution, in this instance the experience of disability momentarily serves as the source of Oedipus's interpretive mastery. Yet, Sophocles' willingness to represent disability as a mode of experience-based knowledge proves a rare literary occasion and a fleeting moment in the play's dramatic structure (Mitchell \& Snyder, 2000, p. 61).

It is precisely here that Katurian's narrations of 'child murders' give the impression of a similarity in terms of causation and discordance. In the play, the different behavioural

2 This is another coinage by Mitchell and Snyder. According to them, "disability also serves as a metaphorical signifier of social and individual collapse. Physical and cognitive anomalies promise to lend a'tangible' body to textual abstractions; we term this metaphorical use of disability the materiality of metaphor" (205). 
and symptomatic manifestations of 'materiality of metaphor' are found not only in the personal presentation of the characters, but also in the implotment of each story. One of the aspects that possibly also influenced the worsening of Katurian's depression and helped him create the 'riddles' in child murders is his familial 'disabilities'. In his family history, there are several cases of psychopathological disorders; his parents were observed to have mental problems and spent most of their life in psychological depression. His parents tried to abuse his brother Michal several times. This fact certainly affected Katurian's psychological life and his stories so much that, in his narrations, there was no normal ending; nearly all stories ended up with different murders. In the introduction of the first story titled 'The Little Apple Men', Katurian explains his psychoanalytic crisis in the following words:

TUPOLSKI. The father.

ARIEL. “He's a ... something, you said.

TUPOLSKI. He represents something, does he?

KATURIAN. He represents a bad father. He is a bad father. How do you mean "represents"?

TUPOLSKI. He is a bad father.

KATURIAN. Yes. He slaps the little girl around.

TUPOLSKI. This is why he is a bad father.

KATURIAN. Yes.

TUPOLSKI. What else does he do to the little girl, "he is a bad father"?

KATURIAN. All the story says, I think, is the father treats the little girl badly. You can draw your own conclusions. (p. 9)

Katurian here invites Tupolski to solve a 'riddle' which can only be solved depending on two expressions: 'How do you mean "represents"?' and 'You can draw your own conclusions.' This is in fact related to the functionality of analytical intelligence, nonetheless these two statements are not enough to solve the riddle. Therefore, it is necessary to make further inquiries for the solution of the riddle. For this reason Tupolski continues his interrogations, and from time to time the questioning is done by Ariel. In Ariel's interrogation, another factor emerges that possibly strengthens the issue of pathological identification and the consequent outbreaks, and this is related to Michal's education and the absence of social life in his infancy. He seems to have no contact with other children of his age. As expressed here: "ARIEL. You collect your brother, he's older than you, he still goes to school? 
KATURIAN. It's a special school. It's a learning difficulties. (Pause.) (p. 11)" In these narrations-just like the ones addressed above-besides the use of loneliness and childhood, the employment of disability discourse by McDonagh is particularly prevalent, as "the narrative is enabled through the prosthetic addition of disability" (Higl, 2012, p. 98). Since the play requires a solution to incorporate the concept of 'disability' as a problem, and since the solution is also related to the solution of the 'riddle', new challenges arise as the interrogation continues. In the forthcoming interrogations, what turns out to be interesting is that the psychoanalytical readings that occur in Michal's childhood are also present in Ariel's, one of the detectives. The narratives behind the spiritual crises are actually a number of childhood memories. So Ariel is empathetic to Michal and is trying to understand him instead of questioning him. That's what Tupolski says about Ariel:

TUPOLSKI. Well, Ariel had a problem childhood, see, and he tends to take it out on all the retards we get in custody. It's bad, really, if you think about it.

KATURIAN. What have you done to him?!

ARIEL. Y'know, you being such an upstart and shouting all over the place, I would usually have smashed your face in by now, but because I've just been doing that to your subnormal brother, my hand really hurts, so for now I'm just going to let you off with a very stern warning. (p. 18)

Ariel's understanding of Michal is similar to what Mitchell and Snyder put forth in Oedipus' riddle-solving, as Ariel's "own disability served as an experiential source for this insight" (2000, p. 61). However, his exposure to violence from one side also provides a tendency towards violence.

The play traces Antonin Artaud's The Theatre of Cruelty, but the text feels more of a 'Disability Theatre'. This in fact originates from literary production as well as from cultural production. In a different chapter, Mitchell and Snyder submit that "the writer and disability as the representational object of the writer's discourse situate themselves more dynamically with respect to the culture within which they are produced" (p. 26). In this way they claim that the involvement of disability studies in literary works is directly related to cultural interaction and they label such initiative production as "literary and cultural investment" (p. 48). McDonagh combines social 
senses with distinct cultural variants: he gives the concepts of fear, voice, hallucination, and so forth, an identity and thus dissolves the 'existential' aspects of 'disabled' characters in cultural society. In the play, the characters show the evident traces of psychotic depression through experiencing hallucinations, memory loss, slow movements, and lack of mind, interesting sounds and bloody clothes. Katurian lives under the threat of his narratives, which indicates the connection of McDonagh's literary investment. Like other people in a state of deep depression, Katurian's characters are surrounded by people, whom he controls with his stories of murders and by whom he is controlled in the attempt to avoid his brother's murder or the worsening of the symptoms. But he always hears an undisclosed voice intoned by a boy:

KATURIAN. (Boy's voice.) Oh. Do all little boys of my age hear such sounds of abomination nightly?

MOTHER. No, my darling. Only the extraordinarily talented ones.

KATURIAN. (Boy's voice.)... (A note in red writing slips under door. Katurian picks it up.) ... a note which read: "They have loved you and tortured me for seven straight years for no reason other than as an artistic experiment, an artistic experiment which has worked. (p. 23)

McDonagh's narrative, as in this quote, contains a set of systematic thinking and includes a sort of ingenuity. The reason for such an implotment is both to create a problem around 'disability' and to make sense of 'literary investment' since "[d] isability is a product of an interaction between all of these positions that create and re-create the disabled body as a potent product of literary investment" (2000, p. 27). The concept of 'disability' that the playwright puts to the centre causes him to be more productive because each story analysis represents a different sick mood. As Katurian talks about his own writings, he tries to make a connection between reality and fiction, and the 'riddle' I mentioned earlier slowly begins to be resolved. The reader suddenly begins to feel the detective role of Tupolski and Ariel in him; the role of detective in the play suddenly bursts into the reader. This confirms that the author has made an awesome 'literary investment' in using 'disabled' characters.

The suffering of the two takes place through the intense and constant projective identifications, giving rise to feelings of anger and guilt towards their torturing parents. Maybe the most striking scene of the play is that in which Katurian suffocates 
his relatives, father, mother and brother respectively; in killing them he totally identified with his ill-health and inanition, expressing an intense suffering and a strong wish to kill anyone around him. The first is the murder of his father:

...his brother he found in there, alive, as such, but brain-damaged beyond repair, and that that night, whilst his parents were sleeping, the fourteenyear-old birthday boy held a pillow over his father's head for a little while... (Katurian suffocates his Father with a pillow. His body spasms, then dies. He taps his Mother on the shoulder. She opens her sleepy eyes to see her open-mouthed dead husband.) ... and, after waking her a moment just to let her see her dead blue husband, he held a pillow over his mothers head for a little while, too. (Katurian, face blank, holds a pillow over his screaming Mothers head Her body spasms wildly, but he forcefully keeps the pillow down, as the lights slowly fade to black.) (p. 25)

Katurian seems to live in a state of dysthymia, manifested by his apathy, lack of interest and mind, the latter taking place particularly through narrating stories by which McDonagh emphasizes that "the disabled body represents a potent symbolic site of literary investment" (Mitchell \& Snyder, 2000, p. 49). With his parents, Katurian dissembles his sadness, because he feels psychologically depressed, not being happy with what they give him. His brother perceives his unhappiness and tries to keep him alive by making him remember that everything is a 'story': "KATURIAN. Why are we being so stupid? Why are we believing everything they're telling us? MICHAL. Why? KATURIAN. This is just like storytelling" (Mcdonagh, 2003, p. 28). The successful storytelling happens as the "last act" of anger and guilt before the decision for the murder. Within the story of 'The Pillowman', McDonagh gives the suspicion of a mental disability; Katurian plans to kill any person around. With regard to this plan, it could be said that it has similar functions to those inferred previously in relation to other planning in the stories.

KATURIAN. Whenever a man or a lady was very very sad because they'd had a dreadful and hard life and they just wanted to end it all, they just wanted to take their own lives and take all the pain away, well, just as they were about to do it, by razor, or by bullet, or by gas, or ...

MICHAL. Or by jumping off of something big.

KATURIAN. Yes. By whatever preferred method of suicide - "preferred"'s 
probably the wrong word, but anyway, just as that person was about to do it, the Pillowman would go to them, and sit with them, and gently hold them, and he'd say, "Hold on a minute," and time would slow strangely, and as time slowed, the Pillowman would go back in time to when that man or that lady was just a little boy or a little girl, to when the life of horror they were to lead hadn't quite yet begun, and the Pillowman's job was very very sad, because the Pillowman's job was to get that child to kill themselves, and so avoid the years of pain that would just end up in the same place for them anyway: facing an oven, facing a shotgun, facing a lake. (p. 31)

Detective inquiries and conversations proceed towards resolution, and ultimately overcome the two 'disabled' characters that are fairly closed, resolving quickly. In this respect, the 'disabled' characters are quite 'closed' first, because "disability also operates as the textual obstacle that causes the literary operation of open-endedness to close down or stumble" (Mitchell \& Snyder, 2000, p. 50). On this note, Katurian and Michal's mentally 'disabled' characterization leads to the closure of the text. However, the vital experience of other characters (including their disabilities) contributes to the resolution of this closure. It could also be probable to relate Katurian's and Michal's depressive states to the concept of 'materiality of metaphor'. This is due to the fact that the materiality of metaphor is reflected with the intensity of their selfabsorbed targets which represent their 'cognitive anomalies' that take them to either social or individual collapse. With regard to the detectives, the control made by Katurian and Michal concerning their appearance and behaviourism is clearly perceptible, once they in fact neglect such aspects. Katurian and Michal prove dissimilar psychosomatic indications: lack of concern, unhappiness, aggression, cynicism, lack of enthusiasm, aloneness, resentment, social abandonment among others. This is also the representation of social collapse, because it is a society exposed to the pressure of the totalitarian regime, just as it is the individual who is subjected to parental oppression. Hence, McDonagh secretly exposes the factors that lead to the formation of the metaphorically disabled individual/society. Such factors allow us to attribute to this play a structure of 'Disability Theatre' in which the most severe level of depression is characterized by 'cognitive anomalies'. Nearly every narrative produced by Katurian is a differing segment of 'collapse' in which the cultural investment is done through psychological troubles recalling some noteworthy metaphors observed within tangible 'childhood' traumas. 
MICHAL. I didn't butcher them. "Butcher them," it'd be more like ... (Michal imitates viciously hacking at someone.) Mine was more like ... (Michal imitates a gentle, single hack onto imaginary toes, then delicately throwing the toes away ... ) And ... (Michal imitates placing two applemen inside a little mouth, then swallowing.) "Butcher them." That's a bit strong. And I wouldn't have done anything if you hadn't told me, so don't you act all the innocent. Every story you tell me, something horrible happens to somebody. I was just testing out how far-fetched they were. 'Cos I always thought some of 'em were a bit far-fetched. (Pause.) D'you know what? They ain't all that far-fetched.

KATURIAN. How come you never acted out any of the nice ones?

MICHAL. Because you never wrote any nice ones.

KATURIAN. I wrote plenty of nice ones.

MICHAL. Er, yeah, like, two.

KATURIAN. No, I'll tell you why you never acted out any of the nice ones, shall I?

MICHAL. Alright.

KATURIAN. Because you're a sadistic, retarded flicking pervert who enjoys killing little kids, and even if every story l ever wrote was the sweetest thing imaginable, the outcome'd still be the fucking same. (p. 35)

The moment the narratives start to unfold, they turn into confessions. Hence, the narratives formed around 'disability' become confessions that open individual and social collapses. In this regard, this analysis supports the following statement by Mitchell and Snyder: "disability has functioned throughout history as one of the most marked and remarked upon differences that originates the act of storytelling. Narratives turn signs of cultural deviance into textually marked bodies" (2000, p. 54). The main cultural deviance in this play is the psychological traumas exhibited by individuals of a society exposed to a totalitarian regime. So Katurian's narratives are reflected in the manifestation of collective consciousness.

When McDonah's play is evaluated in stages, the "simple schematic of narrative structure" (2000, p. 53) that Mitchell and Snyder address in the context of narrative prosthesis can be interpreted clearly. According to their schema, in the first stage "a deviance or marked difference is exposed to a reader" (p. 53). This is first provided in The Pillowman by Michal as 'mentally-disabled' and Katurian as 'psychologically- 
impaired'. In the second, they argue that "a narrative consolidates the need for its own existence by calling for an explanation of the deviation's origins and formative consequences" (p. 53). This is seen in the stories that Katurian further narrates in which 'the parental abuses' are the 'deviation's origins. In the third comes the idea that "the deviance is brought from the periphery of concerns to the centre of the story to come" (p. 53), which is coordinated through 'mentally-disabled' figures in the play to attract the readers to the centre of the acts by means of the act of storytelling. And the last stage of this schema purports that "the remainder of the story rehabilitates or fixes the deviance in some manner" (p. 53) and this is maintained via the confessions which give the main consideration about fixing the deviance.

\section{Conclusion}

This play by McDonagh includes clues for the concept of narrative prosthesis within disability studies, and thus McDonagh's basic emphasis is also that of Mitchell and Snyder's, as "a narrative issues to resolve or correct-to 'prostheticize' in David Wills's sense of the term-a deviance marked as improper to a social context" (p. 53). An accepted opinion in society is that disabled man has a negation. But how is the existence of this negation reflected in literature? The answer to this question is varied. The figures of the 'disabled' and the 'abled' are imperative signifiers in the history of literary narratives. In many literary works, writers convey 'disability' as an 'other' identity of the character(s). Mcdonagh's characters in The Pillowman portray the characteristics of the narrative prosthesis to a considerable extent. The characters of the playwright provide the inverse characteristics of the concept of 'norm' which provide the measures of the human body.

Using the conflicting points of 'normal' and 'subnormal' and typifying psychopathological identities in his play, McDonagh promotes the identification and the pondering of situations and feelings that are typical of people affected by depression. The condensation of different times and the interconnection between the characters, culture and society-which take place throughout the play-reflect, the universality and temporality of psychic phenomena, as well as the apparent implications and social communications in the depressive and suicidal behaviour. Even though, in his dialogue with Michal, Katurian says "I murdered two people who tortured a child for seven years. You murdered three children who hadn't tortured anybody for any years. There's a difference." (p. 38), the conclusion does not change: 
murder and killing. All this proves the existence of 'disabled individuals' in literary works in the social context. When considered from this angle, it is observed that the authors concentrate mainly on the concept of 'disability' around political aims, and centre their narratives on it. The 'disabled' characters constitute the centre of McDonagh's abovementioned play. Therefore, the centre has exactly the concept of narrative prosthesis.

\section{References}

Barthes, R. (1975). The pleasure of the text. New York, NY: Hill and Wang.

Hall, A. (2016). Literature and disability. New York, NY: Roultedge.

Higl, A. (2012). Playing the canterbury tales: The continuations and additions. Surrey, UK: Ashgate.

Higl, A. (2016). Henryson's textual and narrative prosthesis onto chaucer's corpus: Ceresseid's leprocy and her schort conclusioun. In J. R. Eyler (Ed.), Disability in the middle ages: reconsiderations and reverberations (pp. 167-181). New York, NY: Routledge.

Johnston, K. (2016). Disability theatre and modern drama. London, UK: Bloomsbury.

Lawrence, L. J. (2013). Sense and stigma in the gospels: Depictions of sensory-disabled characters. Oxford, UK: Oxford University Press.

Lennard J. D. (1995). Enforcing normalcy: Disability, deafness and the body. London, UK: Verso.

McDonagh, M. (2003). The pillowman. London, UK: Dramatists Play Service Inc.

Mitchell, D., \& Synder, S. (2000). Narrative prosthesis: Disability and the dependencies of discourse. Ann Arbor, Michigan: University of Michigan Press.

Mitchell, D., \& Synder, S. (2006). Narrative prosthesis and the materiality of metaphor. In L. J. Davis (Ed.), The disability studies reader (pp. 205-216). New York, NY: Routledge.

Mitchell, D., \& Synder, S. (2006). Cultural locations of disability. London, UK: The University of Chicago Press.

Titchkosky, T. (2016). The politics of embracing disability metaphor. In C. Kelly \& M. Orsini (Eds.), Mobilizing metaphor: Art, culture, and disability activism in Canada. Toronto, Ontario: UBC Press. 
